\title{
Study on Seismic Properties of Assembled Monolithic Metro Station Based on Response Deformation Method
}

\author{
Tao Chen ${ }^{1,2,3,4, a}$, Furong Luo ${ }^{1, b}$, Xiuli Du,c, Songmei Li ${ }^{3,4, d}$ and Zongyong \\ Wang $3,4, \mathrm{e}$
}

${ }^{1}$ Beijing MTR Construction Administration Corporation, Beijing 100068, China;

${ }^{2}$ The Key Laboratory of Urban Security and Disaster Engineering, Beijing University of Technology, Beijing 100124, China;

${ }^{3}$ Beijing Rail and Transit Design \& Research Institute Co., Ltd., Beijing 100068, China;

${ }^{4}$ Beijing Rail and Transit Engineering Technology Research Center, Beijing 100068, China;

achentao08@tsinghua.org.cn, bgblfrlsc@sohu.com, cduxiuli@bjut.edu.cn,

dlism2050@126.com, ${ }^{\mathrm{e} v a n d r a g o n @ 126 . c o m ~}$

\begin{abstract}
Keywords: underground structure; assembled monolithic metro station; seismic property; response deformation method; internal force.

Abstract. Assembled monolithic metro station is a potential kind of structure technique to solve a series of problems caused by the cast-in-situ concrete technique used in the traditional construction way of metro station. Seismic properties of this underground structure are modeled and studied based on the response deformation method, different mechanical properties of assembling joints and different strata conditions are considered. Results indicate that its seismic properties possess great sensibility to the mechanical properties of assembling joints, with pillar to be the most sensitive. Thus sufficient attention should be paid to seismic design and construction quality of the assembling joints.
\end{abstract}

\section{Introduction}

With the rapid development of social economy and the steady rise of urbanization level, large-scale constructions of urban rail transit engineering, represented by metro stations and subway tunnels, have been springing up across China these years. However, some urgent problems of the traditional construction way of metro station, that is the cast-in-situ reinforced concrete, are exposed. For example, the material/energy waste and the concrete quality is difficult to control, the mechanization degree and construction speed is low, the construction process cause significant influences to the surrounding environments inevitably, which may lead to complaints of residents, and so on [1].

In order to solve these problems, scholars and engineers are turning attention to the precast concrete structure technique, which has already been applied maturely in residential industry [2-4]. According to the assembly level of precast concrete structures, they can be classified into two types [5,6]: fully assembled and partly assembled, and the latter is also called assembled monolithic concrete structure. Prefabricated components of assembled monolithic concrete structure system are connected via post-pouring belt, thus this assembled system presents less structural integrity loss, in other words, it presents better seismic properties.

Serious damage of subway structures during the 1995 Hanshin-Awaji earthquake made seismic reliability of underground structure receive extensive attention [7-9]. In recent years, frequencies and magnitudes of worldwide earthquakes increased markedly, which make seismic researches and designs of underground structures even more prominent. Thus specific Chinese Norms [10-12] went into effect in the last few years, with the response deformation method [13-15] recommended for seismic calculation and design of metro station. With great application potential, seismic properties of assembled monolithic metro station should be understood. However, there is a great lack of related research achievements and engineering experiences.

In this paper, seismic properties of assembled monolithic metro station are modeled and studied based on the response deformation method which is recommended in the specific Chinese Norm for 
urban rail transit engineering. Then comparative analyses and discussions are performed on different mechanical properties of assembling joints and different strata conditions. And at last, several conclusions about the seismic properties and suggestions for seismic design are provided.

\section{Method and Model}

Method. Based on the response deformation method recommended in Code for Seismic Design of Urban Rail Transit Structures (GB 50909-2014) [12], seismic loads are boiled down to three parts: the soil relative deformation, the soil shear stress at the interface between soil and underground structure, and the inertia force of underground structure, as shown in Fig. 1. The interaction between the structure and the soil is modeled as foundation springs with different stiffness coefficients using the MIDAS GTS-NX software.

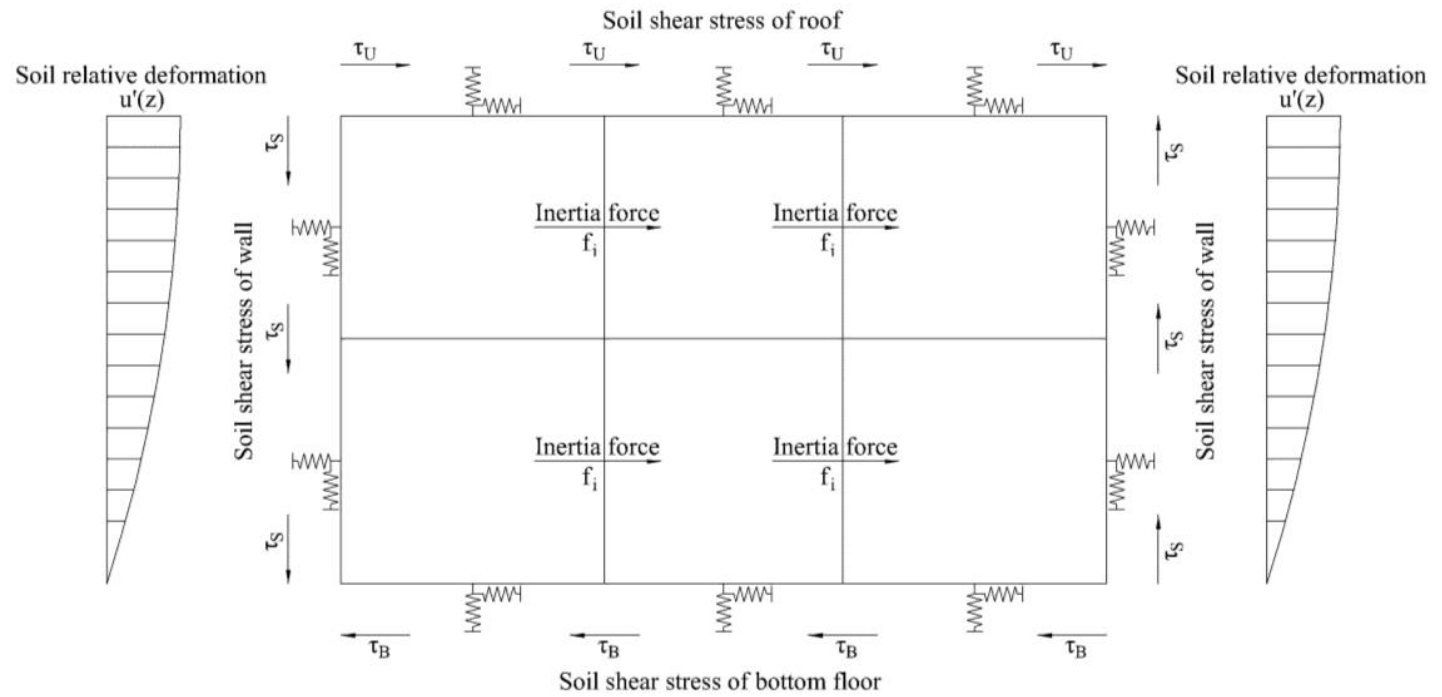

Fig. 1 Calculation model of response deformation method.

Model. Analyses are carried on typical structure style of shallow buried open-cut metro station (triple-span, double-storey and double-pillar), and the assembling joints are positioned combined with its construction process, as shown in Fig. 2. And the equivalent frame method is introduced to model the true stiffness difference between pillars and floors. It is important to note that the bottom floor is still constructed using cast-in-situ concrete to make sure its waterproofness.

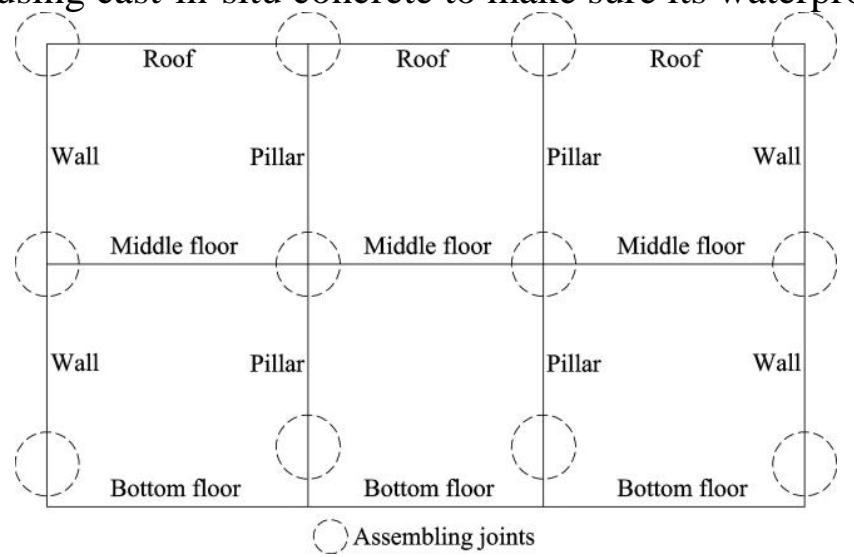

Fig. 2 Structure model of assembled monolithic metro station.

Parameters. Structure dimension parameters of the metro station model are shown in Table 1. And two situations of the assembling joints are considered. First, steel ratio of metro station structure is usually large, and grouting sleeves of the assembling joints will improve their structural rigidity, thus the joints are strengthened comparing to the cast-in-situ ones. In the other case, maybe the construction quality of the assembling joints is poor, or there are other reasons, result in weakened joints. Compared to the cast-in-situ joints, rigidity variation ratios of the assembling joints are set to be 1.4 or 0.8 , in accordance with the previous two cases. Also two common kinds of strata conditions 
(cobble stratum and silty clay stratum) are considered, as shown in Table 2. The seismic datum is chosen to be 60 meters depth for the two strata.

Table 1 Structure dimensions parameters of the metro station.

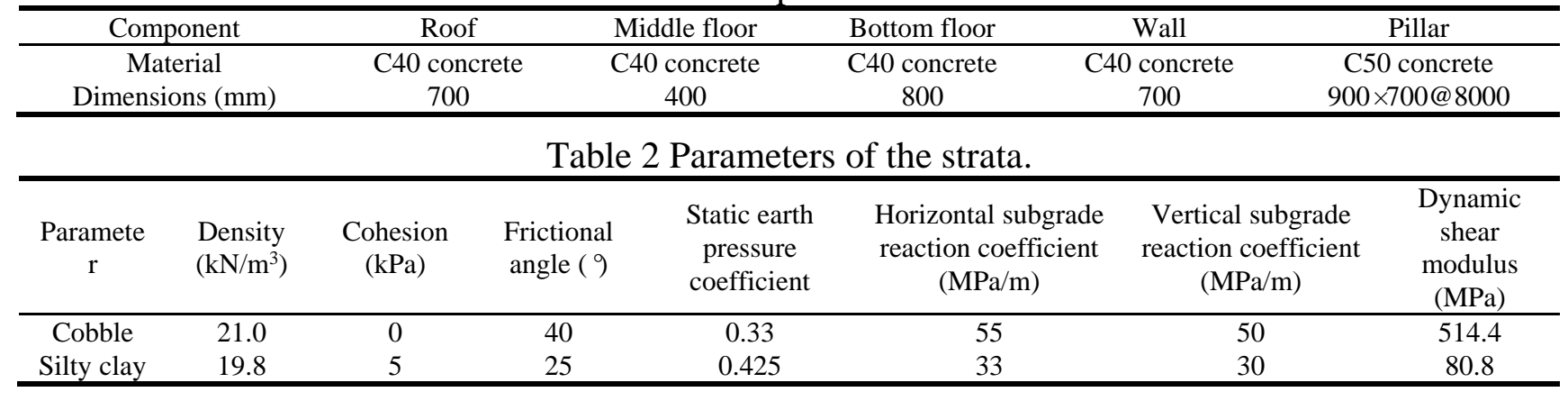

\section{Results and Discussions}

Cobble Stratum. The calculated structural internal forces (per meter length) of metro station in cobble stratum are summarized in Table 3, and the corresponding differences (expressed as percentage relative to the cast-in-situ ones) are shown in Table 4.

Table 3 Structural internal forces of metro station in cobble stratum.

\begin{tabular}{|c|c|c|c|c|c|c|c|c|c|c|}
\hline \multirow{2}{*}{\multicolumn{2}{|c|}{ Position / Internal force }} & \multicolumn{3}{|c|}{ Cast-in-situ } & \multicolumn{3}{|c|}{$\begin{array}{c}\text { Assembled monolithic } \\
\text { (strengthened) }\end{array}$} & \multicolumn{3}{|c|}{$\begin{array}{c}\text { Assembled monolithic } \\
\text { (weakened) }\end{array}$} \\
\hline & & $\begin{array}{c}\text { Bending } \\
\text { moment } \\
(\mathrm{kN} \cdot \mathrm{m})\end{array}$ & $\begin{array}{l}\text { Axial } \\
\text { force } \\
(\mathrm{kN}) \\
\end{array}$ & $\begin{array}{c}\text { Shear } \\
\text { force } \\
(\mathrm{kN})\end{array}$ & $\begin{array}{c}\text { Bending } \\
\text { moment } \\
(\mathrm{kN} \bullet \mathrm{m})\end{array}$ & $\begin{array}{l}\text { Axial } \\
\text { force } \\
(\mathrm{kN})\end{array}$ & $\begin{array}{l}\text { Shear } \\
\text { force } \\
(\mathrm{kN})\end{array}$ & $\begin{array}{c}\text { Bending } \\
\text { moment } \\
(\mathrm{kN} \bullet \mathrm{m})\end{array}$ & $\begin{array}{l}\text { Axial } \\
\text { force } \\
(\mathrm{kN}) \\
\end{array}$ & $\begin{array}{l}\text { Shear } \\
\text { force } \\
(\mathrm{kN})\end{array}$ \\
\hline \multirow{4}{*}{ Roof } & End bearing & 1304 & 815 & 1107 & 1367 & 824 & 1119 & 1255 & 808 & 1097 \\
\hline & $\begin{array}{l}\text { Middle } \\
\text { bearing }\end{array}$ & 478 & 428 & 457 & 501 & 433 & 462 & 461 & 590 & 397 \\
\hline & $\begin{array}{l}\text { Mid-span of } \\
\text { side span }\end{array}$ & 56 & 665 & - & 549 & 671 & - & 582 & 660 & - \\
\hline & $\begin{array}{l}\text { Mid-span of } \\
\text { middle span }\end{array}$ & 70 & 489 & - & 58 & 516 & - & 79 & 486 & - \\
\hline \multirow{4}{*}{$\begin{array}{l}\text { Bottom } \\
\text { floor }\end{array}$} & End bearing & 3267 & 2621 & 1855 & 3304 & 2618 & 1863 & 3236 & 2624 & 1849 \\
\hline & $\begin{array}{l}\text { Middle } \\
\text { bearing }\end{array}$ & 757 & 1184 & 667 & 768 & 1178 & 673 & 748 & 1188 & 662 \\
\hline & $\begin{array}{l}\text { Mid-span of } \\
\text { side span }\end{array}$ & 798 & 618 & - & 812 & 609 & - & 787 & 625 & - \\
\hline & $\begin{array}{l}\text { Mid-span of } \\
\text { middle span }\end{array}$ & 121 & 1499 & - & 120 & 1592 & - & 121 & 1605 & - \\
\hline \multirow{5}{*}{ Wall } & Top bearing & 1456 & 1300 & 711 & 1519 & 1310 & 722 & 1406 & 1293 & 701 \\
\hline & $\begin{array}{l}\text { Middle } \\
\text { bearing }\end{array}$ & 973 & 1093 & 618 & 1021 & 1098 & 629 & 936 & 1089 & 610 \\
\hline & $\begin{array}{l}\text { Bottom } \\
\text { bearing }\end{array}$ & 2992 & 2088 & 2205 & 3032 & 2093 & 2204 & 2959 & 2083 & 2205 \\
\hline & $\begin{array}{l}\text { Mid-span of } \\
\text { top storey }\end{array}$ & 178 & 768 & - & 179 & 769 & - & 177 & 768 & - \\
\hline & $\begin{array}{c}\text { Mid-span of } \\
\text { bottom } \\
\text { storey }\end{array}$ & 827 & 1539 & - & 811 & 1541 & - & 829 & 1599 & - \\
\hline \multirow[b]{2}{*}{ Pillar* } & Top bearing & 1197 & 7527 & 357 & 1347 & 7553 & 405 & 1089 & 7506 & 323 \\
\hline & $\begin{array}{l}\text { Bottom } \\
\text { bearing }\end{array}$ & 2397 & 10866 & 714 & 2553 & 10900 & 766 & 2277 & 10836 & 674 \\
\hline
\end{tabular}

*Structural internal forces of pillar has been converted considering the longitudinal distance between two pillars.

Assembled Monolithic Metro Station with Strengthened Joints. Compared with the cast-in-situ metro station, there is an obvious increase of bending moment in every bearing position for the assembled monolithic metro station with strengthened assembling joints. But bending moments in mid-span positions present different results for different structural components. Mid-span bending moments of roof decrease noticeably. While mid-span bending moments of 
bottom floor and wall present small amplitude increase and decrease simultaneously, for their stronger and more complicated interactions with surrounding soils. As a whole, changes of axial/shear forces of roof, bottom floor and wall are not obvious, except for few mid-spans. In particular, bending moments and shear forces of pillar in all bearing positions increase significantly, which should be paid sufficient attention in seismic design.

Table 4 Structural internal force differences of metro station in cobble stratum.

\begin{tabular}{|c|c|c|c|c|c|c|c|}
\hline \multirow{2}{*}{\multicolumn{2}{|c|}{$\begin{array}{l}\text { Position / Internal force } \\
\text { difference ratio }\end{array}$}} & \multicolumn{3}{|c|}{ Assembled monolithic (strengthened) } & \multicolumn{3}{|c|}{ Assembled monolithic (weakened) } \\
\hline & & \multirow{2}{*}{$\begin{array}{c}\begin{array}{c}\text { Bending moment } \\
(\%)\end{array} \\
4.775\end{array}$} & \multirow{2}{*}{$\begin{array}{c}\begin{array}{c}\text { Axial force } \\
(\%)\end{array} \\
1.104\end{array}$} & \multirow{2}{*}{$\begin{array}{c}\text { Shear force } \\
(\%)\end{array}$} & \multirow{2}{*}{$\begin{array}{c}\text { Bending moment } \\
(\%)\end{array}$} & \multirow{2}{*}{$\begin{array}{c}\text { Axial force } \\
(\%) \\
-0.902\end{array}$} & \multirow{2}{*}{$\begin{array}{l}\text { Shear force } \\
(\%) \\
-0.874\end{array}$} \\
\hline \multirow{4}{*}{ Roof } & End bearing & & & & & & \\
\hline & Middle bearing & 4.895 & 1.257 & 1.049 & -3.457 & 38.042 & -13.069 \\
\hline & $\begin{array}{l}\text { Mid-span of side } \\
\text { span }\end{array}$ & -3.180 & 0.846 & - & 2.584 & -0.723 & - \\
\hline & $\begin{array}{l}\text { Mid-span of } \\
\text { middle span }\end{array}$ & -16.189 & 5.655 & - & 13.710 & -0.671 & - \\
\hline \multirow{4}{*}{$\begin{array}{l}\text { Bottom } \\
\text { floor }\end{array}$} & End bearing & 1.118 & -0.128 & 0.390 & -0.944 & 0.087 & -0.337 \\
\hline & Middle bearing & 1.446 & -0.439 & 0.896 & -1.145 & 0.346 & -0.722 \\
\hline & $\begin{array}{l}\text { Mid-span of side } \\
\text { span }\end{array}$ & 1.758 & -1.485 & - & -1.417 & 1.176 & - \\
\hline & $\begin{array}{l}\text { Mid-span of } \\
\text { middle span }\end{array}$ & -0.574 & 6.190 & - & 0.429 & 7.054 & - \\
\hline \multirow{5}{*}{ Wall } & Top bearing & 4.304 & 0.730 & 1.606 & -3.433 & -0.586 & -1.294 \\
\hline & Middle bearing & 4.924 & 0.464 & 1.650 & -3.858 & -0.364 & -1.310 \\
\hline & Bottom bearing & 1.328 & 0.254 & -0.051 & -1.116 & -0.224 & 0.022 \\
\hline & $\begin{array}{l}\text { Mid-span of top } \\
\text { storey }\end{array}$ & 0.523 & 0.014 & - & -0.495 & -0.031 & - \\
\hline & $\begin{array}{c}\text { Mid-span of } \\
\text { bottom storey }\end{array}$ & -1.895 & 0.099 & - & 0.317 & 3.875 & - \\
\hline \multirow{2}{*}{ Pillar } & Top bearing & 12.543 & 0.339 & 13.400 & -9.013 & -0.280 & -9.583 \\
\hline & Bottom bearing & 6.498 & 0.317 & 7.276 & -5.008 & -0.270 & -5.555 \\
\hline
\end{tabular}

Assembled Monolithic Metro Station with Weakened Joints. Compared with the cast-in-situ metro station, internal forces in the same positions of the assembled monolithic metro station with weakened assembling joints basically present an opposite trend. However, axial forces in middle bearing of roof and mid-span of middle span of bottom floor break this rule. Further analyses reveal that opposite mechanical properties of assembling joints have change the distribution regularities of peak bending moment between two middle bearings. Thus distribution regularities of seismic internal forces for assembled monolithic metro station are affected greatly by the assembling joints.

Silty Clay Stratum. The calculated structural internal forces (per meter length) of metro station in silty clay stratum are summarized in Table 5, and the corresponding differences (expressed as percentage relative to the cast-in-situ ones) are shown in Table 6.

Table 5 Structural internal forces of metro station in silty clay stratum.

\begin{tabular}{|c|c|c|c|c|c|c|c|c|c|c|}
\hline \multirow{2}{*}{\multicolumn{2}{|c|}{ Position / Internal force }} & \multicolumn{3}{|c|}{ Cast-in-situ } & \multicolumn{3}{|c|}{$\begin{array}{l}\text { Assembled monolithic } \\
\text { (strengthened) }\end{array}$} & \multicolumn{3}{|c|}{$\begin{array}{l}\text { Assembled monolithic } \\
\text { (weakened) }\end{array}$} \\
\hline & & Bending & Axial & Shear & Bending & Axial & Shear & Bending & Axial & Shear \\
\hline \multirow{5}{*}{ Roof } & & & & & & & & & & \\
\hline & End bearing & 702 & 409 & 550 & 727 & 411 & 552 & 681 & 406 & 548 \\
\hline & $\begin{array}{l}\text { Middle } \\
\text { bearing }\end{array}$ & 414 & 361 & 353 & 431 & 364 & 355 & 400 & 359 & 351 \\
\hline & $\begin{array}{l}\text { Mid-span of } \\
\text { side span }\end{array}$ & 341 & 306 & - & 332 & 309 & - & 348 & 304 & - \\
\hline & $\begin{array}{l}\text { Mid-span of } \\
\text { middle span }\end{array}$ & 97 & 338 & - & 87 & 339 & - & 106 & 337 & - \\
\hline Bottom & End bearing & 1674 & 1181 & 976 & 1690 & 1178 & 978 & 1660 & 1183 & 974 \\
\hline
\end{tabular}




\begin{tabular}{|c|c|c|c|c|c|c|c|c|c|c|}
\hline \multirow[t]{3}{*}{ floor } & $\begin{array}{l}\text { Middle } \\
\text { bearing }\end{array}$ & 410 & 856 & 518 & 415 & 853 & 520 & 406 & 858 & 517 \\
\hline & $\begin{array}{l}\text { Mid-span of } \\
\text { side span }\end{array}$ & 542 & 768 & - & 543 & 763 & - & 541 & 771 & - \\
\hline & $\begin{array}{l}\text { Mid-span of } \\
\text { middle span }\end{array}$ & 208 & 927 & - & 209 & 923 & - & 208 & 931 & - \\
\hline \multirow{5}{*}{ Wall } & Top bearing & 769 & 617 & 368 & 794 & 619 & 372 & 748 & 616 & 366 \\
\hline & $\begin{array}{c}\text { Middle } \\
\text { bearing }\end{array}$ & 619 & 758 & 532 & 649 & 759 & 537 & 596 & 758 & 529 \\
\hline & $\begin{array}{l}\text { Bottom } \\
\text { bearing }\end{array}$ & 1597 & 1104 & 1051 & 1615 & 1105 & 1049 & 1582 & 1103 & 1053 \\
\hline & $\begin{array}{c}\text { Mid-span of } \\
\text { top storey }\end{array}$ & 166 & 588 & - & 161 & 565 & - & 169 & 587 & - \\
\hline & $\begin{array}{c}\text { Mid-span of } \\
\text { bottom } \\
\text { storey } \\
\end{array}$ & 420 & 910 & - & 406 & 909 & - & 432 & 910 & - \\
\hline \multirow[b]{2}{*}{ Pillar* } & Top bearing & 840 & 6737 & 256 & 945 & 6737 & 290 & 765 & 6735 & 232 \\
\hline & $\begin{array}{l}\text { Bottom } \\
\text { bearing }\end{array}$ & 1267 & 8696 & 383 & 1343 & 8693 & 409 & 1208 & 8697 & 364 \\
\hline
\end{tabular}

*Structural internal forces of pillar has been converted considering the longitudinal distance between two pillars.

Table 6 Structural internal force differences of metro station in silty clay stratum.

\begin{tabular}{|c|c|c|c|c|c|c|c|}
\hline \multirow{2}{*}{\multicolumn{2}{|c|}{$\begin{array}{l}\text { Position / Internal force } \\
\text { difference ratio }\end{array}$}} & \multicolumn{3}{|c|}{ Assembled monolithic (strengthened) } & \multicolumn{3}{|c|}{ Assembled monolithic (weakened) } \\
\hline & & \multirow{2}{*}{$\begin{array}{c}\begin{array}{c}\text { Bending moment } \\
(\%)\end{array} \\
3.612\end{array}$} & \multirow{2}{*}{$\begin{array}{c}\begin{array}{c}\text { Axial force } \\
(\%)\end{array} \\
0.624\end{array}$} & \multirow{2}{*}{$\begin{array}{c}\text { Shear force } \\
(\%)\end{array}$} & \multirow{2}{*}{$\begin{array}{c}\text { Bending moment } \\
(\%) \\
-2.936\end{array}$} & \multirow{2}{*}{$\begin{array}{c}\begin{array}{c}\text { Axial force } \\
(\%)\end{array} \\
-0.526\end{array}$} & \multirow{2}{*}{$\begin{array}{c}\text { Shear force } \\
(\%) \\
-0.369\end{array}$} \\
\hline \multirow{4}{*}{ Roof } & End bearing & & & & & & \\
\hline & Middle bearing & 4.072 & 0.721 & 0.749 & -3.275 & -0.577 & -0.566 \\
\hline & $\begin{array}{l}\text { Mid-span of side } \\
\text { span }\end{array}$ & -2.689 & 0.833 & - & 2.156 & -0.628 & - \\
\hline & $\begin{array}{l}\text { Mid-span of } \\
\text { middle span }\end{array}$ & -10.527 & 0.417 & - & 8.887 & -0.353 & - \\
\hline \multirow{4}{*}{$\begin{array}{l}\text { Bottom } \\
\text { floor }\end{array}$} & End bearing & 0.973 & -0.257 & 0.192 & -0.836 & 0.185 & -0.171 \\
\hline & Middle bearing & 1.355 & -0.355 & 0.424 & -1.043 & 0.271 & -0.328 \\
\hline & $\begin{array}{l}\text { Mid-span of side } \\
\text { span }\end{array}$ & 0.166 & -0.586 & - & -0.115 & 0.452 & - \\
\hline & $\begin{array}{l}\text { Mid-span of } \\
\text { middle span }\end{array}$ & 0.184 & -0.470 & - & -0.151 & 0.356 & - \\
\hline \multirow{5}{*}{ Wall } & Top bearing & 3.272 & 0.294 & 0.876 & -2.658 & -0.242 & -0.723 \\
\hline & Middle bearing & 4.777 & 0.139 & 0.877 & -3.687 & -0.106 & -0.673 \\
\hline & Bottom bearing & 1.120 & 0.089 & -0.224 & -0.954 & -0.083 & 0.155 \\
\hline & $\begin{array}{l}\text { Mid-span of top } \\
\text { storey }\end{array}$ & -2.455 & -3.840 & - & 2.098 & -0.055 & - \\
\hline & $\begin{array}{c}\text { Mid-span of } \\
\text { bottom storey }\end{array}$ & -3.398 & -0.050 & - & 2.716 & 0.025 & - \\
\hline \multirow{2}{*}{ Pillar } & Top bearing & 12.495 & 0.008 & 13.200 & -9.007 & -0.021 & -9.516 \\
\hline & Bottom bearing & 6.016 & -0.034 & 6.592 & -4.665 & 0.006 & -5.069 \\
\hline
\end{tabular}

Although numerical values of the internal forces in the same positions are much smaller for different seismic loads coming from different strata, the relative change rates of the internal forces in the same positions are generally consistent. Once again it should be pointed out emphatically that bending moments and shear forces of pillar change significantly for different assembling joints.

It can be further concluded from the above discussions that the seismic properties of assembled monolithic metro station possess great sensibility to the mechanical properties of assembling joints. Thus seismic design and construction quality of the assembling joints will determine seismic safety of assembled monolithic metro station to a large extent. 


\section{Conclusions and suggestions}

Based on the response deformation method recommended in Code for Seismic Design of Urban Rail Transit Structures (GB50909-2014), seismic properties of assembled monolithic metro station are modeled and studied. Analyses and discussions are performed considering different mechanical properties of assembling joints and different strata conditions combined with its construction process. And several conclusions and engineering suggestions are proposed herein:

(1) Compared with the cast-in-situ metro station, there is an obvious increase of bending moment in every bearing position for the assembled monolithic metro station with strengthened assembling joints. And this law will be converse in case of weakened assembling joints.

(2) Seismic properties of assembled monolithic metro station possess great sensibility to the mechanical properties of assembling joints.

(3) Pillar is the most sensitive component to the mechanical properties of assembling joints.

(4) Seismic design and construction quality of the assembling joints, which will determine seismic safety of assembled monolithic metro station to a large extent, should be paid sufficient attention.

As can be seen, results of these calculations are applicative for the presupposed conditons (i.e., parameters of joints and strata). Thus experimental evidences and engineering experiences are demanded to fill the vacancy on the potential assembled monolithic metro station.

\section{Acknowledgements}

This work was financially supported by the Science and Technology Project Plan of Ministry of Housing and Urban-Rural Development (2016-K5-016).

\section{References}

[1] Y.P. Xu: Architecture, No.15, (2013) 8-9. (In Chinese)

[2] V. Martha: PCI Journal, Vol.51, No.1, (2006) 42-61.

[3] Q.J. Jiang: Architecture Technology, Vol.41, No.12, (2010) 1074-1077. (In Chinese)

[4] Q. Liu, X.M. Li, Q.F. Xu: Construction Technology, Vol.43, No.22, (2014) 9-14,43. (In Chinese)

[5] Technical Specification for Precast Concrete Structures, (JGJ 1-2014). (In Chinese)

[6] W. Zhang: Doctoral Dissertation of Chang'an University, Xi'an, (2015). (In Chinese)

[7] S. Samata, H. Ohuchi, T. Matsuda: Cement and Concrete Composites, Vol.19, No.3, (2010) 223-239.

[8] Y.M.A. Hashash, J.J. Hook, B. Schmidt, J.I. Yao: Tunneling and Underground Space Technology, Vol.16, (2001) 247-293.

[9] X. Yu, Y.T. Zhao, Z.K. Guo: Under Ground Space, Vol.21, No.1, (2001) 28-32,43. (In Chinese)

[10] Code for Seismic Design of Buildings, (GB 50011-2010). (In Chinese)

[11] Code for Design of Urban Rail Transit, (DB 11/995-2013). (In Chinese)

[12] Code for Seismic Design of Urban Rail Transit Structures, (GB 50909-2014). (In Chinese)

[13] H.W. Qi: Railway Construction Technology, Vol.S2, (2012) 100-103. (In Chinese)

[14] J.B. Liu, W.H. Wang, X.B. Zhang, D.D. Zhao: Chinese Journal of Rock Mechanics and Engineering, Vol.32, No.1, (2013) 161-167. (In Chinese)

[15] L. Liang, X.H. Yang, X.L. Du: Chinese Journal of Geotechnical Engineering, Vol.36, No.7, (2014) 1360-1364. (In Chinese) 